\title{
MECHANICAL PARAMETERS OF THERMALLY MODIFIED ASH WOOD DETERMINED ON COMPRESSION IN TANGENTIAL DIRECTION
}

\author{
Waldemar Moliński ${ }^{1}$, Edward Roszyk ${ }^{1, \triangleq}$, Aleksander Jabłoński, ${ }^{1}$ \\ Jakub Puszyński ${ }^{1}$,Janusz Cegieta ${ }^{1}$
}

\begin{abstract}
Mechanical parameters of ash wood (Fraxinus excelsior) subjected to compression in tangential direction, before and after its thermal modification and measured at the moisture content close to the equilibrium moisture content of wood used inside and outside the house, (4 and 12\%) were compared. Thermal modification of wood was performed at $190^{\circ} \mathrm{C}$ and $200^{\circ} \mathrm{C}$ for 2 hours in industrial conditions. During the measurements, the moisture content of the modified and control samples was the same. The parameters compared included: modulus of elasticity, stress at proportionality limit, relative linear strain at proportionality limit and accumulated elastic energy. Thermal modification of ash wood at $190^{\circ} \mathrm{C}$ contributed to the deterioration of its mechanical parameters determined during compression in tangential direction; the deterioration was greater for wood tissue of higher moisture content. The values of mechanical parameters of thermally modified wood (except for elastic energy), determined in compression test in tangential direction, decrease with the its increasing moisture more than for the control wood.
\end{abstract}

Keywords: Fraxinus excelsior, mechanical properties, modulus of elasticity, stress-strain relation, thermally modified wood.

\section{INTRODUCTION}

Mechanical parameters of wood compressed in perpendicular to the grains are heavily dependent on the direction of acting stresses relative to the annual ring orientation (Green et al. 1999, Gibson and Ashby 1997, Lung et al. 2002, Clauss et al. 2014, Niemz et al. 2014) as well as on the conditions under which the stresses act. Knowledge of wood resistance to compressive stresses acting in perpendicular to the grains is essential when evaluating wood resistance to load distributed over the entire specimen surface or local (Pellicane et al. 1994, Ethington et al. 1996, Hoffmeyer et al. 2000). Differentiated wood structure of many wood species and its variability over the radius and at different heights makes the description of wood mechanical properties very complicated. Moreover, the relation of mechanical properties in particular directions depends on moisture content of wood (Ozyhar et al. 2012). Mechanical properties of thermally modified wood depend not only on heat treatment parameters, but also on wood species and the property examined (Boonstra et al. 2007). For example tensile strength along and perpendicular to the grains, shear strength, and impact and dynamic bending strength always deteriorate after thermal modification (ThermoWood ${ }^{\circledR}$ Handbook 2003, Windeisen et al. 2009). According to the study by Li Shi et al. (2007) on a few Canadian wood species, thermal modification of wood results in a substantial decrease in its resistance to static bending and a slight decrease in the modulus of elasticity. For modified birch and ash wood the modulus of elasticity was even 15-30\% higher than for unmodified wood. It is clear that the type of modified wood affects its hardness. For softwoods like pine, spruce or birch, the increase in hardness both in the longitudinal and in tangential direction was

${ }^{1}$ Department of Wood Science, Faculty of Wood Technology, Poznań University of Life Sciences, Poznań, Poland.

•Corresponding author: eroszyk@up.poznan.pl

Received: 27.04.2016 Accepted: 09.12.2017 
usually observed, and the largest increase in its value was observed on frontal planes. However, for thermally modified ash wood its hardness in all directions was lower than for unmodified wood. It has to be mentioned that the changes in mechanical properties of wood - the direction of these changes - depends on mass loss of wood caused by its heating. Borrega and Kärenlampi (2008), analyzing the properties of thermally modified wood as a function of its mass loss, proved that the strength, deformations at the moment of failure and impact strength decreased with increased mass loss of wood caused by its thermal treatment. On the other hand, stiffness started to decrease only when the mass loss of thermally treated wood rose above 3\%. Mixed literature reports on the effect of thermal treatment of wood on its mechanical parameters are partly a result of comparison of these properties with analogous parameters of unmodified wood, which means that the equilibrium moisture contents of the compared wood tissues were different. (Arnold 2010, Moliński et al. 2010). Responsible for the changes in the values of mechanical parameters of wood after thermal modifications and for the impact of moisture on their change, which is higher than for unmodified wood, are the changes in basic chemical composition (mainly in CML), microstructural defects (Esteves and Pereira 2009) and changes in the arrangement of compounds in cellular wall (Olek and Bonarski 2008, Olek et al. 2013).

According to the latest studies by the authors of this work, mechanical parameters of ash wood modified at $190^{\circ} \mathrm{C}$ for 2 hours, determined in a compression test in radial direction, are higher than for unmodified wood, but only for the wood of moisture content of ca. $4 \%$. For those of the moisture content close to $12 \%$, the modified wood showed lower values of conventional specific strength, modulus of elasticity and elastic energy (Moliński et al. 2016). Only the deformations on elastic limit were similar for both wood tissues. Modification of this wood at $200^{\circ} \mathrm{C}$ resulted in a decrease in all analyzed parameters, regardless of the moisture content at the moment of determination. Similar observations about the impact of moisture content of pine and spruce thermally modified wood on compressive strength along the grains, bending and MOE can be found in the publication by Icel et al. (2015). It has to be emphasized that the change in mechanical parameters of wood after its thermal modification can be related to its initial density. Moliński et al. (2016) have observed that the higher the wood density before the modification, the greater the increase in the density of thermally modified ash wood. In analysis of mechanical parameters of wood in tangential directions, the wood density affected them to different extents. For example, the study by Burgert et al. (2011) on 12 hardwood species has shown that the modulus of elasticity of wood in radial direction depends mostly on wood rays tissue content and to a smaller extent on wood density, while in tangential direction it seems to depend only on its density.

This article presents a comparison of mechanical parameters of ash wood compressed in tangential direction before and after its thermal modifications, determined by the moisture content close to the equilibrium value of wood used inside and outside the house.

\section{MATERIALS AND METHODS}

Ten radial boards of $25 \mathrm{~mm}$ in thickness and $1 \mathrm{~m}$ long, divided in two sets of 5 planks, were tested. Control samples were made from each board by cutting off a section of $0,35 \mathrm{~m}$ in length; the rest was thermally treated. Thermal treatment of the boards was performed at $190^{\circ} \mathrm{C}$ for one set of planks and at $200^{\circ} \mathrm{C}$ for the other. Both sets of boards were modified for 2 hours in industrial conditions, in accordance with the procedure by Finnforest (ThermoWood ${ }^{\circledR}$ Handbook 2003). Figure 1 presents the way the boards were divided into control parts and the parts destined for modification, and how the samples were obtained. 


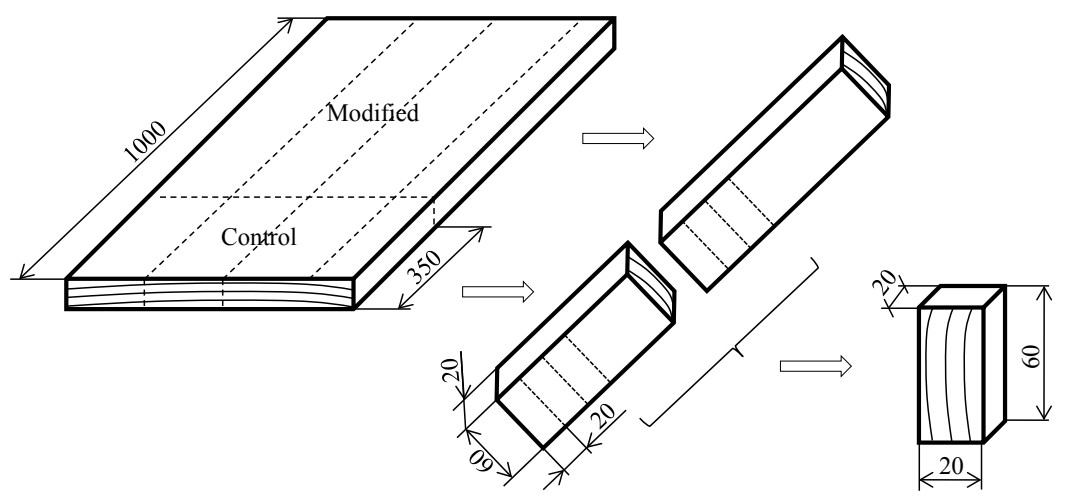

Figure 1. The way the boards were divided for the study.

After thermal treatment all wood samples were conditioned in open air under a roof for seven days. Then, the control parts and the corresponding modified parts of the boards were set together and lines for their cutting were drawn along both parts. The fillets obtained from both parts of the boards after sawing included the same annual rings. The sawing along both parts of the boards was performed in such a way to reduce their length on both sides to $60 \mathrm{~mm}(\mathrm{R})$. Next, the boards were whittled away to $20 \mathrm{~mm}$ in thickness (T). From the wood pieces prepared like that, samples of $20 \mathrm{~mm}$ length (L) were cut off. Two identical sets were made of selected samples and then stored in conditions guaranteeing the moisture content of ca. $4 \%$ for the first set and the equilibrium moisture content of ca. $12 \%$ for the other set. Taking into account the results reported by Moliński et al. (2010) about the hygroscopicity of similar wood material, it was decided to condition thermally modified wood at room temperature in desiccators. The modified samples were conditioned at the relative humidity ( $\mathrm{RH}$ ) of $45 \%$ or $97 \%$ and the control samples at the relative humidity of $25 \%$ or $80 \%$.

The measurements of mechanical parameters of wood compressed perpendicularly to the grains were performed using a numerically controlled test machine Zwick Z050 in accordance to the norm PN-77/D-04229. The data obtained were then used to compute the modulus of elasticity values (MOE), accumulated elastic energy (U), relative linear strain at proportionality limit $\left(\sigma_{g p}\right)$, stress at proportionality limit and stress vs. strain plot $\left(\varepsilon_{g p}\right)$. The parameters are indicated in Figure 2. 


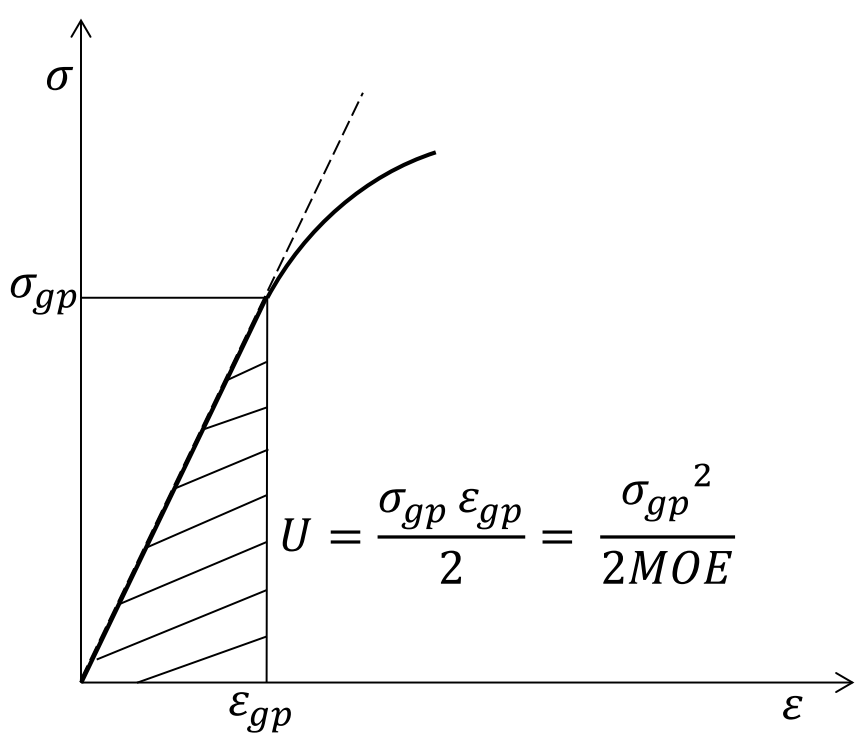

Figure 2. The s-e dependence and the parameters measured on the sample compression in the tangent direction.

\section{RESULTS AND DISCUSSION}

Because mechanical parameters of wood compressed in tangential direction depend on its density, it was decided to discuss the influence of thermal treatment on the change in this property in the first place. The results of density determination for all wood samples of low moisture content used for the study are collected in Table 1, along with the information about the average wood density after thermal treatment. As wood modification in chosen temperatures was conducted on different batches of material (T1 and T2), the initial densities of wood were slightly different (on average by about $6 \%$ ). Wood moisture at which the wood density parameter was determined was $3,8-4,2 \%$ for control samples $2,8-4,3 \%$ for the wood modified at $190^{\circ} \mathrm{C}$ and $2,3-3,6 \%$ for the wood modified at $200^{\circ} \mathrm{C}$. As shown in Table 1., wood density after thermal treatment slightly decreased - by $3,4 \%$ and by $4,2 \%$ for the wood modified at $190^{\circ} \mathrm{C}$ and $200^{\circ} \mathrm{C}$ respectively. The causes of wood density decrease after thermal modification have been the subject of consideration of many researchers and, as it turns out, it is mainly caused by evaporation of volatile compounds and products of degradation of wood components, especially the least stable hemicelluloses.

Table 1. Average values of wood density in control samples (C) and thermally modified wood (MT) at $\mathrm{T} 1=190^{\circ} \mathrm{C}$ and at $\mathrm{T} 2=200^{\circ} \mathrm{C}$ determined at the moisture content of ca. $4 \%$.

\begin{tabular}{|l|l|l|l|}
\hline Density, $\rho\left[\mathrm{kg} / \mathrm{m}^{3}\right]$ & \multirow{2}{*}{$\begin{array}{c}\text { Average change } \\
\text { density, [\%] }\end{array}$} \\
\cline { 1 - 3 } Control & Modified $190^{\circ} \mathrm{C}$ & Modified $200^{\circ} \mathrm{C}$ & \\
\hline min-avg-max & min-avg-max & min-avg-max & \\
\hline $556-613-647(\mathrm{~T} 1)$ & $530-592-625$ & - & $-3,4$ \\
\hline $545-576-603(\mathrm{~T} 2)$ & - & $519-552-591$ & $-4,2$ \\
\hline
\end{tabular}


Table 2, Table 3, Table 4, Table 5 present the mechanical parameters of analyzed wood samples. The results for the samples thermally modified at $190^{\circ} \mathrm{C}$ or $200^{\circ} \mathrm{C}$ (the moisture content of $4 \%$ ) and for the control samples are collected in Table 2 and Table 3 . The corresponding results determined at the moisture content of $12 \%$ are presented in Table 4 and Table 5. The changes in the mean values of determined parameters, that are the result of wood thermal modification, are also included in the tables. According to the gathered data, the change in wood properties after its thermal modification depends on the temperature at which the modification was performed and on the moisture content at the moment of the measurements.

The wood modified at $190^{\circ} \mathrm{C}$ (moisture content of ca. $4 \%$ ), exhibits comparable to control wood conventional specific strength, understood as the ratio of stress at proportionality limit to wood density. The values of stress at proportionality limit and modulus of elasticity decreased slightly by ca. $3 \%$ and $6,5 \%$ respectively. What decreased significantly was elastic energy (by ca. 10\%) and the value of strain at proportionality limit (by ca. 10\%). It has to be noted that mechanical parameters of this wood, determined during compression in radial direction, reached higher values after thermal treatment at this temperature than the same wood before modifications (Moliński et al. 2016). It is probably wood rays that are responsible for such a distribution of wood mechanical parameters after its thermal treatment as in this case they are compressed crosswise. According to Burgert and Eckstein (2001), the mechanical strength of wood rays in the axial direction is comparable with that of the bulk wood tissue. As follows from literature, the mechanical parameters of wood modified in the longitudinal direction, especially under a relatively mild thermal treatment, can be even higher than those of the initial wood (ThermoWood ${ }^{\circledR}$ Handbook 2003, Li Shi et al. 2007, Windeisen et al. 2009). Precise explanation of these differences needs further studies.

Determined at this moisture level the mechanical parameters of wood modified at $200^{\circ} \mathrm{C}$, except the modulus of elasticity, were significantly worse than those determined for control wood. Elastic energy and strain at proportionality limit diminished mostly, by over $20 \%$. Comparing the changes in these parameters to the changes in the analogous parameters of the wood subjected to thermal treatment at $190^{\circ} \mathrm{C}$, it can be concluded that wood tissue fragility substantially increased with increasing modification temperature. Similar conclusions have been drawn by Murata et al. (2013), who studied of wood cracking for spruce wood thermally modified at temperatures $120-200^{\circ} \mathrm{C}$ in the RL system (cracking in the tangent plane) and TL system (cracking in the radial plane) forced by the bending of samples with an appropriate notch. They have observed a clear decrease in the energy of destruction and deformation already after the treatment at $150^{\circ} \mathrm{C}$. Because starting from this modification temperature also the fiber saturation point (FSP) also considerably decreased, these authors have interpreted this result as a consequence of changes in hemicelluloses leading to reduction of adsorption sites.

Table 2. Mechanical parameters of control wood and wood modified at $190^{\circ} \mathrm{C}$, moisture content of $4 \%$.

\begin{tabular}{|c|c|c|c|c|}
\hline \multirow[b]{2}{*}{ Mechanical parameter } & \multicolumn{4}{|c|}{ Basic statistical parameters } \\
\hline & $\min -a v g-\max$ & $\begin{array}{c}\text { Mean } \\
\text { change }[\%]\end{array}$ & $\begin{array}{l}\text { Standard deviation, } \\
\qquad \pm \mathrm{S}\end{array}$ & $\begin{array}{c}\text { Variability } \\
\text { coefficient, V [\%] }\end{array}$ \\
\hline $\begin{array}{l}\text { Stress at proportionality } \\
\text { limit, } \sigma_{\mathrm{gp}}[\mathrm{MPa}]\end{array}$ & $\begin{array}{c}5,26-6,32-7,59^{*} \\
4,10-6,11-6,80\end{array}$ & $-3,3$ & $\begin{array}{l}0,78 \\
0,66\end{array}$ & $\begin{array}{l}12,33 \\
10,73\end{array}$ \\
\hline $\begin{array}{c}\text { Strain at proportionality } \\
\text { limit, } \varepsilon_{\mathrm{gp}}[\%]\end{array}$ & $\begin{array}{l}0,51-0,76-1,01 \\
0,57-0,64-0,69\end{array}$ & $-15,8$ & $\begin{array}{l}0,18 \\
0,03\end{array}$ & $\begin{array}{c}23,35 \\
5,40\end{array}$ \\
\hline $\begin{array}{l}\text { Modulus of elasticity, } \\
\text { MOE [MPa] }\end{array}$ & $\begin{array}{c}949-1044-1171 \\
709-976-1143\end{array}$ & $-6,5$ & $\begin{array}{l}58,65 \\
98,65\end{array}$ & $\begin{array}{c}5,62 \\
10,11\end{array}$ \\
\hline Elastic energy, $\mathrm{U}[\mathrm{J}]$ & $\begin{array}{l}0,336-0,551-0,731 \\
0,299-0,493-0,579\end{array}$ & $-10,5$ & $\begin{array}{l}0,15 \\
0,07\end{array}$ & $\begin{array}{l}27,78 \\
13,39\end{array}$ \\
\hline $\begin{array}{c}\text { Conventional specific } \\
\text { strength, } \sigma \text { gpw } \\
\text { x } 10^{2}\end{array}$ & $\begin{array}{l}0,96-1,10-1,26 \\
0,76-1,11-1,27\end{array}$ & 0,0 & $\begin{array}{l}0,11 \\
0,13\end{array}$ & $\begin{array}{l}10,04 \\
11,62\end{array}$ \\
\hline
\end{tabular}


Table 3. Mechanical parameters of control wood and wood modified at $200^{\circ} \mathrm{C}$, moisture content of $4 \%$.

\begin{tabular}{|c|c|c|c|c|}
\hline \multirow[b]{2}{*}{ Mechanical parameter } & \multicolumn{4}{|c|}{ Basic statistical parameters } \\
\hline & min-avg-max & $\begin{array}{c}\text { Mean change } \\
{[\%]}\end{array}$ & $\begin{array}{c}\text { Standard deviation, } \\
\pm \mathrm{S}\end{array}$ & $\begin{array}{c}\text { Variability } \\
\text { coefficient, V [\%] }\end{array}$ \\
\hline $\begin{array}{l}\text { Stress at proportionality } \\
\text { limit, } \sigma_{\mathrm{gp}}[\mathrm{MPa}]\end{array}$ & $\begin{array}{c}5,73-7,49-9,05^{*} \\
5,60-6,83-9,50\end{array}$ & $-8,8$ & $\begin{array}{l}1,05 \\
1,40\end{array}$ & $\begin{array}{l}14,05 \\
20,46\end{array}$ \\
\hline $\begin{array}{l}\text { Strain at proportionality } \\
\text { limit, } \varepsilon_{\mathrm{gp}}[\%]\end{array}$ & $\begin{array}{l}0,53-0,97-1,42 \\
0,57-0,75-1,12 \\
\end{array}$ & $-22,7$ & $\begin{array}{l}0,26 \\
0,17\end{array}$ & $\begin{array}{l}26,95 \\
22,98\end{array}$ \\
\hline $\begin{array}{c}\text { Modulus of elasticity, } \\
\text { MOE [MPa] }\end{array}$ & $\begin{array}{l}651-960-1171 \\
869-985-1149 \\
\end{array}$ & $+2,6$ & $\begin{array}{l}172,53 \\
85,05\end{array}$ & $\begin{array}{c}17,98 \\
8,64\end{array}$ \\
\hline $\begin{array}{c}\text { Elastic energy, } \\
\text { U }[J]\end{array}$ & $\begin{array}{l}0,372-0,793-1,077 \\
0,400-0,630-1,193\end{array}$ & $-20,6$ & $\begin{array}{l}0,24 \\
0,25\end{array}$ & $\begin{array}{l}29,81 \\
40,28\end{array}$ \\
\hline $\begin{array}{c}\text { Conventional specific } \\
\text { strength, } \sigma \quad[\mathrm{MNm} / \\
\mathrm{kg}] \times 10^{2}\end{array}$ & $\begin{array}{l}0,91-1,22-1,41 \\
0,92-1,15-1,53\end{array}$ & $-5,7$ & $\begin{array}{l}0,15 \\
0,19\end{array}$ & $\begin{array}{l}12,48 \\
16,45\end{array}$ \\
\hline
\end{tabular}

The variability in the parameters of control and thermally modified wood at the higher moisture content is higher, as shown in Table 4 and Table 5. It means that thermally modified wood, subjected to analogous changes in moisture as control wood, changes its properties to a greater extent than control wood. It is especially evident for the wood modified at $190^{\circ} \mathrm{C}$ (Table 4). To relate to this observation, a comparison of real changes in moisture of tested materials has to be made. In Table 6 the ranges of real moisture content for respective sample groups are presented. According to the data, the samples modified and conditioned over a water table reached the moisture content of ca. $4 \%$ higher than control samples conditioned over an oversaturated $\mathrm{NaCl}$ solution. The changes in given parameters of tested samples corresponding to the moisture content increase from the first to the second moisture level were calculated. Such calculations were made only for the mean values of measured parameters, because of slight differences in the moisture content of respective sample populations.

Table 4. Mechanical parameters of control wood and wood modified at $190^{\circ} \mathrm{C}$, moisture content ca. $12 \%$.

\begin{tabular}{|c|c|c|c|c|}
\hline \multirow[b]{2}{*}{ Mechanical parameter } & \multicolumn{4}{|c|}{ Basic statistical parameters } \\
\hline & min-avg-max & $\begin{array}{c}\text { Mean change } \\
{[\%]}\end{array}$ & $\begin{array}{c}\text { Standard deviation, } \\
\pm \mathrm{S}\end{array}$ & $\begin{array}{c}\text { Variability } \\
\text { coefficient, V [\%] }\end{array}$ \\
\hline $\begin{array}{l}\text { Stress at proportionality } \\
\text { limit, } \sigma_{\mathrm{gp}}[\mathrm{MPa}]\end{array}$ & $\begin{array}{c}4,00-4,98-5,86^{*} \\
2,59-3,17-3,57\end{array}$ & $-36,4$ & $\begin{array}{l}0,50 \\
0,39\end{array}$ & $\begin{array}{c}9,99 \\
12,16\end{array}$ \\
\hline $\begin{array}{l}\text { Strain at proportionality } \\
\text { limit, } \varepsilon_{\mathrm{gp}}[\%]\end{array}$ & $\begin{array}{l}0,50-0,87-1,31 \\
0,61-1,06-1,64\end{array}$ & $+21,8$ & $\begin{array}{l}0,26 \\
0,34 \\
\end{array}$ & $\begin{array}{l}29,31 \\
32,20\end{array}$ \\
\hline $\begin{array}{c}\text { Modulus of elasticity, } \\
\text { MOE [MPa] }\end{array}$ & $\begin{array}{l}480-698-842 \\
222-348-443\end{array}$ & $-50,1$ & $\begin{array}{c}129,63 \\
68,27 \\
\end{array}$ & $\begin{array}{l}18,58 \\
19,62\end{array}$ \\
\hline $\begin{array}{c}\text { Elastic energy, } \\
\mathrm{U}[\mathrm{J}]\end{array}$ & $\begin{array}{l}0,254-0,500-0,716 \\
0,207-0,435-0,711\end{array}$ & $-13,0$ & $\begin{array}{l}0,14 \\
0,17 \\
\end{array}$ & $\begin{array}{l}28,64 \\
38,14\end{array}$ \\
\hline $\begin{array}{c}\text { Conventional specific } \\
\text { strength, } \sigma_{\mathrm{gpw}}[\mathrm{MNm} / \mathrm{kg}] \\
\mathrm{x} 10^{2}\end{array}$ & $\begin{array}{c}0,62-0,78-0,90 \\
0,48-0,54-0,58\end{array}$ & $-32,1$ & $\begin{array}{l}0,08 \\
0,03\end{array}$ & $\begin{array}{c}10,27 \\
6,08\end{array}$ \\
\hline
\end{tabular}


Table 5. Mechanical parameters of control wood and wood modified at $200^{\circ} \mathrm{C}$, moisture content ca. $12 \%$.

\begin{tabular}{|c|c|c|c|c|}
\hline \multirow{2}{*}{ Mechanical parameter } & \multicolumn{3}{|c|}{ Basic statistical parameters } \\
\cline { 2 - 5 } & min-avg-max & $\begin{array}{c}\text { Mean } \\
\text { change [\%] }\end{array}$ & $\begin{array}{c}\text { Standard } \\
\text { deviation, } \pm \mathrm{S}\end{array}$ & $\begin{array}{c}\text { Variability } \\
\text { coefficient, V [\%] }\end{array}$ \\
\hline $\begin{array}{c}\text { Stress at proportionality } \\
\text { limit, } \sigma_{\mathrm{gp}}[\mathrm{MPa}]\end{array}$ & $\begin{array}{c}3,86-4,78-6,00^{*} \\
3,21-3,52-4,07\end{array}$ & $-26,4$ & 0,73 & 15,30 \\
\hline Strain at proportionality & $0,58-0,83-1,23$ & $+12,1$ & 0,26 & 7,39 \\
\hline limit, $\varepsilon_{\text {gp }}[\%]$ & $0,61-0,93-1,49$ & & 0,26 & 32,10 \\
\hline Modulus of elasticity, & $527-658-764$ & $-35,0$ & 76,80 & 29,34 \\
MOE [MPa] & $269-428-562$ & 71,68 \\
\hline Elastic energy, & $0,287-0,481-0,790$ & $-14,1$ & 0,20 & 17,50 \\
\hline U [J] & $0,263-0,413-0,679$ & & 0,13 & 31,09 \\
\hline Conventional specific & $0,64-0,80-1,05$ & $-23,8$ & 0,13 & 15,92 \\
strength, $\sigma$ gpw $[\mathrm{MNm} / \mathrm{kg}]$ & $0,57-0,61-0,69$ & & 0,03 & 5,05 \\
X10 & & & \\
\hline
\end{tabular}

Table 6. Variability of moisture content in analyzed sample populations.

\begin{tabular}{|l|l|l|l|}
\hline \multirow{3}{*}{ Material } & \multicolumn{2}{|l|}{ Moisture content [\%] } & $\begin{array}{l}\text { Mean difference in } \\
\text { moisture content }\end{array}$ \\
\cline { 2 - 4 } & low & high & $\Delta \mathrm{u}[\%]$ \\
\cline { 2 - 4 } & min-avg-max & min-avg-max & 9,68 \\
\hline Control sample $\mathrm{T}_{1}$ & $2,40-2,65-2,89$ & $11,86-12,33-12,77$ & 13,76 \\
\hline $\begin{array}{l}\text { Sample modified at } \\
\mathrm{T}_{1}=190^{\circ} \mathrm{C}\end{array}$ & $2,91-4,05-4,89$ & $16,53-17,81-19,05$ & 9,05 \\
\hline Control sample $\mathrm{T}_{2}$ & $2,52-3,09-4,13$ & $11,79-12,14-12,52$ & 12,69 \\
\hline $\begin{array}{l}\text { Sample modified at } \\
\mathrm{T}_{2}=200^{\circ} \mathrm{C}\end{array}$ & $2,26-2,40-3,62$ & $14,03-15,09-16,11$ & \\
\hline
\end{tabular}

The change in the values of analyzed properties were calculated using the following Equation 1:

$$
\Delta W=\frac{W_{1}-W_{2}}{\Delta u}[M P a / \%] ;[J / \%][\% / \%]
$$

where: $D W$ is the change in a given parameter corresponding to the moisture content increase by one percent, $W_{1}$ is the mean value of a given parameter at lower moisture content, $W_{2}$ is the mean value of a given parameter at higher moisture content, and $\mathrm{D} u$ is the mean difference in moisture content for a given population.

The values calculated in this way are collected in Table 7. According to these data, the influence of the increase in wood moisture content on the measured mechanical parameters is, except for elastic energy, slightly higher for thermally modified wood than for unmodified wood. Lower impact of wood moisture increase on the elastic energy of modified wood indicates permanent, irreversible increase in the wood tissue fragility. Hughes et al. (2015), in their studies on the impact strength, pointed out great influence of hemicelluloses on the values of energy of destruction and on the interactions of water and cellular wall components. According to the mentioned authors, hemicelluloses act as an interfacial coupling agent, as they enhance the contact between cellulose microfibrils and another matrix component - lignin. Thus destruction of hemicelluloses during thermal modification process not only decreases sorptive properties of wood but also has a huge impact on its mechanical properties. 
Table 7. Relative changes of mechanical parameters of control and thermally modified wood per $1 \%$ increase in the moisture content of the samples.

\begin{tabular}{|c|c|c|c|c|}
\hline \multirow{2}{*}{ Rodzaj materiału } & $\begin{array}{c}\text { Stress at } \\
\text { proportionality limit }\end{array}$ & Modulus of elasticity & Elastic energy & $\begin{array}{c}\text { Conventional } \\
\text { specific strength }\end{array}$ \\
\hline & \multicolumn{4}{|c|}{$\begin{array}{l}\text { Relative change corresponding to moisture content increase by } 1 \% \\
\text { (a coefficient) }\end{array}$} \\
\hline Control sample $T_{1}$ & 0,0346 & 0,0289 & 0,0381 & 0,0373 \\
\hline $\begin{array}{l}\text { Sample modified at } \\
\mathrm{T}_{1}=190^{\circ} \mathrm{C}\end{array}$ & 0,0389 & 0,0470 & 0,0225 & 0,0385 \\
\hline Control sample $\mathrm{T}_{2}$ & 0,0269 & 0,0408 & 0,0141 & 0,0301 \\
\hline $\begin{array}{l}\text { Sample modified at } \\
\mathrm{T}_{2}=200^{\circ} \mathrm{C}\end{array}$ & 0,0334 & 0,0442 & 0,0128 & 0,0355 \\
\hline $\begin{array}{l}\text { Control sample } \\
\text { (mean) }\end{array}$ & 0,0308 & 0,0349 & 0,0261 & 0,0337 \\
\hline $\begin{array}{l}\text { Modified sample } \\
\text { (mean) }\end{array}$ & 0,0362 & 0,0456 & 0,0177 & 0,0370 \\
\hline
\end{tabular}

\section{CONCLUSIONS}

Presented results allow to draw the following conclusions:

The process of thermal modification of wood causes a decrease in its density - the higher the temperature of the process the greater the decrease in density. These results confirm the earlier literature reports.

The ash wood modified at $190^{\circ} \mathrm{C}$ and of moisture content close to $4 \%$ shows the conventional specific strength, understood as the ratio of stress at the proportionality limit to wood density, similar to that of the control wood. However, in comparison to the control wood, the above ash wood shows a little lower stress at the proportionality limit and modulus of elasticity as well as a significantly lower capability of deformation and accumulation of elastic energy.

At this level of moisture content, the ash wood modified at $200^{\circ} \mathrm{C}$ reveals a more pronounced deterioration of the parameters measured. The exception is the linear elasticity modulus whose value is comparable to that of the control wood.

The impact of increased wood moisture content on the mechanical parameters measured (except for the elastic energy) is by $10-30 \%$ greater on the thermally modified wood than on the unmodified wood. The lower effect of increased wood moisture content on elastic energy of the modified wood indicates the permanent and irreversible increase in the brittleness of this wood.

\section{REFERENCES}

Arnold, M. 2010. Effect of moisture on the bending properties of thermally modified beech and spruce. Journal of Materials Science 45(3): 669-680.

Boonstra, M.J.; Van Acker, J.; Tjeerdsma, B.F.; Kegel E.F. 2007. Strength properties of thermally modified softwoods and its relation to polymeric structural wood constituents. Ann For Sci 64(7): 679-690.

Borrega, M.; Kärenlampi, P.P. 2008. Mechanical behavior of heat-treated spruce (Picea abies) 
wood at constant moisture content and ambient humidity. European Journal of Wood and Wood Products 66(1): 63-69.

Burgert, I.; Bernasconi, A.; Niklas, K.J.; Eckstein, D. 2011. The influence of rays on the transverse elastic anisotropy in green wood of deciduous trees. Holzforschung 55(5): 449-454.

Burgert, I.; Eckstein, D. 2001. The tensile strength of isolated wood rays of beech (Fagus sylvatica L.) and its significance for the biomechanics of living trees. Trees 15(3): 168-170.

Clauss, S.; Pescatore, C.; Niemz, P. 2014. Anisotropic elastic properties of common ash (Fraxinus excelsior L.). Holzforschung 68(8): 941-949.

Esteves, B.M.; Pereira, H.M. 2009. Wood modification by heat treatment: A review. BioResources 4(1): $370-404$.

Ethington, R. L.; Eskelsen, V.; Gupta, R. 1996. Relationship between compression strength perpendicular to grain and ring orientation. Forest Products Journal 46(1): 84-86.

Gibson, L. J.; Ashby, M.F. 1997. Cellular solids. Structural and properties. Second edition. Cambridge University Press, Cambridge, UK.

Green, D.W.; Winandy J.E.; Kretschmann, D.E. 1999. Mechanical properties of wood. Wood handbook: Wood as an engineering material. Madison, WI: USDA Forest Service, Forest Products Laboratory.

Hoffmeyer, P.; Damkilde, L.; Pedersen, T.N. 2000. Structural timber and glulam in compression perpendicular to grain. Holz Roh Werkst 58(1): 73-80.

Hughes, M.; Callum Hill, C.; Pfriem, A. 2015. The toughness of hygrothermally modified wood. Holzforschung 69(7): 851-862.

Icel, B.; Guler, G.; Isleyen, O.; Beram, A.; Mutlubas, M. 2015. Effect of industrial heat tretment on the properties of Spruce and Pine woods. BioResources 10(3): 5159-5173.

Li Shi, J.; Kocaefe, D.; Zhang, J. 2007. Mechanical behavior of Qu'ebec wood species heattreated using ThermoWood process. Holz Roh Werkst 65(4): 255-259.

Lung, E. M.; Bejo, L.; Szalai, J.; Kovacs, Z.; Anderson, B.R. 2002. Orthotropic strength and elasticity of hardwoods in relation to composite manufacture. Part II. Orthotropy of compression strength and elasticity. Wood and Fiber Science 14(2): 350-365.

Moliński, W.; Fabisiak, E.; Środecki, L. 2010. Selected mechanical properties of thermally modified American Ash wood. Annals of WULS. Forestry and Wood Technol 72: 32-36.

Moliński, W.; Roszyk, E.; Jabłoński, A.; Puszyński, J.; Cegieła, J. 2016. Mechanical parameters of thermally modified ash wood determined on compression in radial direction. Maderas-Cienc Tecnol 18(4):577-586.

Murata, K.; Watanabe, Y.; Nakano, T. 2013. Effect of thermal treatment on fracture properties and adsorption properties of Spruce wood. Materials 6(9): 4186-4197.

Niemz, P.; Clauss, S.; Michel, F.; Hänsch, D.; Hänsel, A. 2014. Physical and mechanical properties of common ash (Fraxinus excelsior L.). Wood Research 59 (4): 671-682.

Olek, W.; Bonarski, J.T. 2008. Texture changes in thermally modified wood. Archives of Metallurgy and Materials 53(1): 207-211.

Olek, W.; Majka, J.; Czajkowski, L. 2013. Sorption isotherms of thermally modified wood. Holzforschung 67(2): 183-191.

Ozyhar, T.; Hering, S.; Niemz, P. 2012. Moisture-dependent orthotropic tension-compression asymmetry of wood. Holzforschung 67(4): 395-404. 
Pellicane, P. J.; Bodig, J.; Mrema, A. L. 1994. Behavior of wood in transverse compression. Journal of Testing and Evaluation 22(4): 383-387.

Polish Committee for Standardization. PN. 1977. Wood. Determination of compression strength across the grain. PN-77/D-04229-1977. (Oznaczanie wytrzymałości na ściskanie w poprzek włókien.)

Thermowood $^{\circledR}$ Handbook. 2003. Finnish Thermowood Association, Helsinki [Online]. Available: $<$ https://asiakas.kotisivukone.com/files/en.thermowood.palvelee.fi/downloads/tw_handbook_080813. pdf $>$ [Accessed 2018-03-14].

Windeisen, E.; Bächle, H.; Zimmer, B.; Wegener, G. 2009. Relations between chemical changes and mechanical properties of thermally treated wood. Holzforschung 63(6): 773-778. 